C. В. Капустин [S. V. Kapustin]

P. Ф. Халабия [R. F.Khalabia]

УДК 004.735

\title{
СИСТЕМА ОЦЕНКИ ЭНЕРГОЭФЕКТИВНОСТИ СИНХРОНИЗИРОВАННОГО ДОСТУПА В ИМИТАЦИОННОЙ МОДЕЛИ БЕСПРОВОДНОЙ СЕНСОРНОЙ СЕТИ
}

\author{
SYSTEM FOR EVALUATING THE ENERGY EFFICIENCY \\ OF SYNCHRONIZED ACCESS IN A SIMULATION MODEL \\ OF A WIRELESS SENSOR NETWORK
}

МИРЭА - Российский технологический университет, Россия, г. Ставрополь / MIREA - Russian Technological University, Russia, Stavropol

\begin{abstract}
Аннотация. В статье исследуются энергоэффективность узлов в структуре илитационной модели синхронизированного доступа беспроводной сенсорной сети, приводятся обоснования и доказательства применения имитационного моделирования на основе метода Time Division Multiple Access (TDMA), для оценки надежсности используется алгорити определения пути $f$ узла к базовой станции в нижней границе оценки стабильности. Основной задачей исследуемого сиихронизированного доступа канального уровня является настройка временных параметров протокола. Предложенная илитационная модель исправляет дефекть спецификаџии сети и производит оџенку объема в момент передачи и за единицу времени иа рапнем этапе пастройки архитектуры сети. Осповное преимуцество имитаиионой модели заключается в высокой энергоэффективности беспроводных сенсорных узлов при развертывании беспроводной сенсорной сети.
\end{abstract}

Ключевые слова: алгоритм, автономность работы, бесперебойность, беспроводная сенсорная сеть, синхронизированная сеть, сетевой протокол, маршрутизация, simulation model.

Abstract. The article examines the energy efficiency of nodes in the structure of a simulated model of synchronized access of a wireless sensor network, provides rationale and evidence for the use of simulation based on the Time Division Multiple Access (TDMA) method, to evaluate reliability, an algorithm is used to determine the f path of a node to a base station at the lower boundary of stability assessment. The main task of the investigated synchronized access of the data link layer is to configure the protocol temporal parameters. The proposed simulation model corrects defects in the network specification and estimates the volume at the time of transmission and per unit of time at an early stage of network architecture setup. The main advantage of the simulation model is the high energy efficiency of the wireless sensor nodes when deploying a wireless sensor network.

Key words: algorithm, autonomy, continuity, wireless sensor network, synchronized and asynchronous network, network protocol, routing, channel layer.

Introduction. The functioning of E-Governance, which implements the tasks of the electronic state, is organized in the form of Internet portals, i.e. integrated electronic tools are being created to ensure the implementation of a number of government functions. There is a problem of the quality and reliability of technical means of information and communication services: reliability and quality of database servers, quality of communication channels, reliability of network equipment, etc. This problem, of course, should be solved taking into account the "factor of geographical scales", i.e. the increase in the coverage area of electronic services is accompanied by an increase in the fleet of technical equipment and the number of services for organizing the functioning of communication networks. [1]

One of the promising solutions for sparsely populated regions of Russia is a self-organizing distributed network, which consists of sensor nodes (wireless sensor network). It has reliability, fault tolerance and long battery life, and its purpose is in the collection and transmission of information.

High energy consumption and, as a consequence, a decrease in the autonomy of the wireless sensor network nodes is associated with the use of asynchronous access. The time synchronization schedule of nodes can increase the availability of information reception and transmission while maintaining energy reserves at the time of active operation of the network. Reducing the discharge of the battery pack and increasing the speed of transmitted packets occurs due to the process of data aggregation.

The article discusses the issues of substantiation and evidence using simulation based on the TDMA method (Time Division Multiple Access - time division multiple access) [2]. The primary task of which is the modeling of the data link layer and the classification of the upper level, and the secondary task is the model of the physical layer. With such a formalization of the model, it is possible to adjust the level of complexity of the physical level. Make settings for the model and debug the channel, network levels, this is necessary to detail the wireless network model.

Materials and methods. Simulation of a wireless sensor network

The process of introducing a physical layer model into a network model is a feature of modeling a sensor network. In the protocol stack of the TinyOS network operating system (Fig. 1), data is transmitted between nodes at the physical level and checked for collisions in the channel to calculate the probability of packet delivery [3]. A lightweight access model with preliminary verification in the channel is used. Simulation of the transmission of individual bits in 
the channel, taking into account the signal power between nodes located in the reach zone, is necessary when implementing a complicated model.

To route packets in the user-level application interface, channel-level capabilities are applied at the network level. The amount of network-level load depends heavily on the level of network performance and the tasks performed by the router.

The presented structure in TinyOS demonstrates the possibility of use in the communication space. Changing add-ons of levels smoothly is possible due to a clear distinction between the interface and the level structure [4]. Particular attention is paid to the direct transfer of applications from the simulation model to the real system. In practice, difficulties may arise at the network and channel levels, and this affects the work of the application level [5].

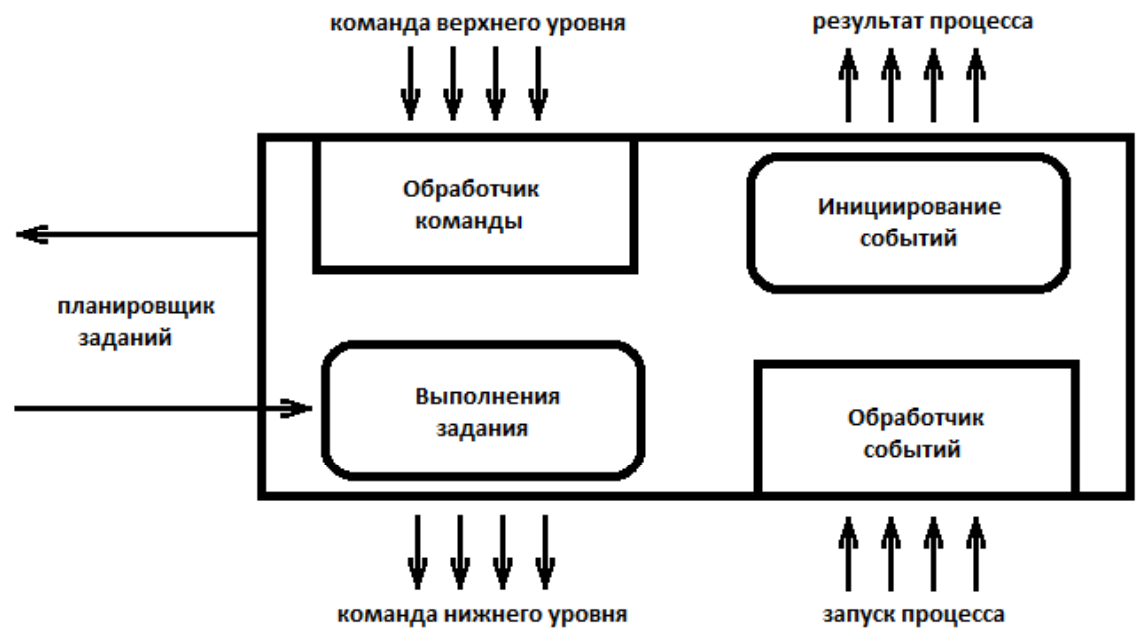

Fig. 1. The structure of the operating platform TinyOS

Software and hardware components are considered the foundation of a wireless sensor network. The software component supports the process of transmitting information to base stations. When new nodes appear on the network or when the node fails, the transfer is carried out taking into account changes in the network configuration. This is the principle of self-organization of the network, i.e. there is a redistribution of the flow direction in the nodes towards the base station (Fig. 2).

Time sharing of access in channels using the TDMA scheme increases energy efficiency up to 10 times. When using a synchronized approach when modeling a wireless network, a shift in emphasis occurs. When listening to the network, the energy consumption is reduced and the transmission time increases, which should not exceed the fixed interval for which the receiving node scans the network [6].

When servicing terminal nodes, it is appropriate to use no more than one router node, in which case the scheme will be effective. Using TDMA reduces power consumption, which reduces battery capacity and cost. A factor that increases energy consumption is collisions. But in wireless sensor networks with a high density of nodes, the network stops working.

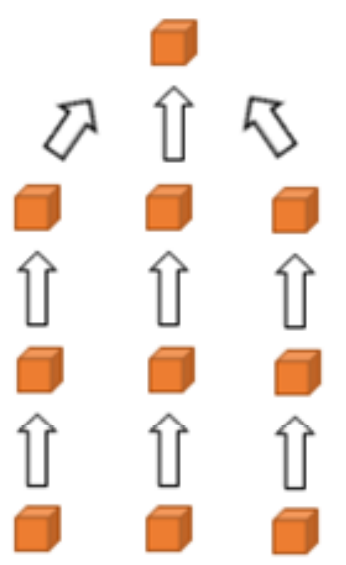

a)

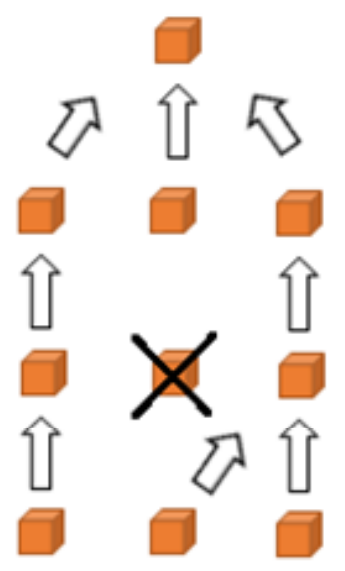

б)

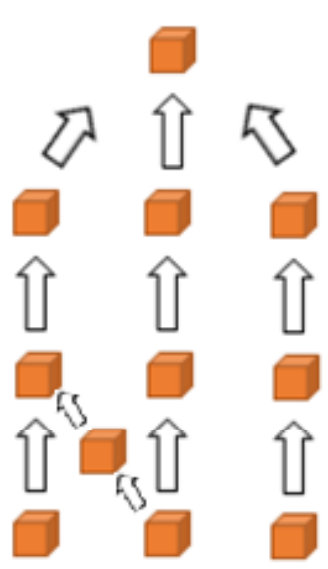

в)

Fig. 2. Options for redistributing a wireless network configuration:

a) the organization of a wireless sensor network, b) rebuilding the network at the time of a node failure,

c) building up a wireless network 
For a number of applications, router and application levels can be simplified, but this affects the accuracy of the model. OPERATING SYSTEM TinyOS was specially developed to reconfigure the wireless sensor network and it is possible to introduce new nodes, move and delete nodes.

Wireless sensor networks do not require network configuration changes, so there is no breakdown and the base router works with an immutable route table. The method of changing routes is used in territorial routing due to a geographical factor. In real conditions, in the algorithm, the task of routes, taking into account the factor of geographical scale, is specified as a universal data transmission route.

TinyOS was created for wireless sensor networks based on the concept of distributed offers, adapted for system services. No complex logic decisions and specifications for network management. In the IMPLEMENTED model, the access protocol is DEVELOPED in the channel level of the model, and the model is optimized without changing the interfaces between the levels of the protocol stack.

Results and discussions. Evaluation of fault tolerant structure in a simulation model of a wireless sensor network. Assessing network deployment for functional requirements is called fault tolerance of a wireless network. We apply the approach of accounting for uncertain actions to assess the parameters of the sensor network.

The algorithm of the method is laid down for automated routes:

- determination of the model and verification of the wireless channel of the network;

- requirements for reliability, uninterrupted operation of the network;

- the procedure for calculating the parameters of functions and the location of the sensor network;

- unloading the wireless network and avoiding collisions by identifying transit nodes;

- step-by-step removal of unnecessary nodes during the formation of network structure calculations.

To assess the reliability $P_{f s}^{\prime}$ of the contact of nodes with the base station, an algorithm is used to determine the path $f$ of the node to the base station at the lower boundary of the Litvak-Ushakov stability assessment. The lower bound for the likelihood $F_{C}$ of a node connecting a node to a base station is determined [7]:

$$
P_{f s}^{\prime}=\left(1-Q_{f s}\right)
$$

$Q_{f s}$ - the likelihood that all independent paths from this node $F_{S}$ to the base station are disabled.

$$
Q_{f s}=\prod_{\mu_{f s}^{k} \in M_{f s}} q_{f s}^{k}
$$

$Q_{f s} \mathrm{t}$ - the probability that this independent path $\mu_{f s}^{k}$ between the $f$-node and the base station is faulty.

In a wireless sensor network, information is transmitted according to a given schedule, the number of routes corresponds to the number of paths for transmitting information through $T$ and $\mathrm{f}$ nodes to the base station and correspond to the number of cycles performed by $T$ nodes during the information collection period. The collection of information by the end nodes depends on the time $T$ and periods of breakdowns, $T$ nodes use constant power, which increases operating time, $E_{\text {all }}$ battery capacity, $E_{\text {dis }}$ loss of power charge. $T$ node operates in two positions, this is the discharge of the power source, or in relay mode [8].

To calculate the current consumption time in sleep mode, the average relay current mode is needed, in this case, the current consumption during sleep is less than the average value.

We calculate the probability that the battery will not be discharged on the node for $\mathrm{K}$ the number of relayings.

$$
P_{E}=\frac{1}{2}\left(1+\operatorname{erf}\left(\frac{E_{M U}-K \mu}{\sqrt{2 K \delta^{2}}}\right)\right)
$$

The reliability level of the wireless network structure $P_{f S}^{\prime}$ is determined (1).

The main task of synchronized access of the data link layer is to configure the protocol temporal parameters [9]. With certain accuracy parameters, the nodes should be synchronized in one frame. The TDMA access scheme implemented on the TinyOS platform did not show a complete view of network scalability. However, it was possible to increase the transmission speed of information in a smaller channel. In the implemented scheme, a short period of time is allocated at the beginning of the frame, which determines the states of the nodes.

At the base station, throughput is optimized for information transfer and for autonomy. In the simulation model, the synchronization of the channel level of the wireless network is performed without the use of special equipment. The simulation model uses a four-level wireless network protocol stack. The physical and network layers with fault tracking functionality and a static routing table are used. The application layer consists of rules with a fixed time interval.

To perform specialized tasks and adjust the structure, the health intervals of network segments are estimated. The model corrects defects in the network specification and estimates volume at the time of transmission and per unit of time at an early stage of network architecture configuration. When modeling a protocol with a variable frame length, the throughput increases.

Comparing this simulation model with a previously developed model that uses the adaptive route selection method taking into account the signal-to-noise ratio in the data channel for solving the data transfer problem in the elec- 
tronic state, it was found that the standard deviation of the calculation results does not differ by more than $7 \%$. The probability of failure of nodes in the models is practically the same. The main advantage of the latest simulation model is the gain in electricity.

Conclusion. The article considers a simulated model of synchronized access - as a prototype for creating a wireless sensor network using energy-efficient nodes. The intensity of the use of the information transmission channel uses a 20Ah battery resource for one year, the functioning of router nodes for 5 years.

In the course of the studies, a time-division channel access scheme was used for the channel level model of the wireless sensor network. The model was tested in real conditions, which confirmed the adequacy of the simulation model. Such a solution can be applied to solve the problems of automation of electronic state processes in sparsely populated areas of Siberia and the Far North.

\section{ЛИТЕРА ТУРА}

1. Антонова Г.М., Титов А.П. Е-Governance инструмент электронного государств. -Управление развитием крупномасшттабных систем (MLSD'2011): Материалы Пятой международной конференции. Том 2. М.: ИПУ РАН, 2011. С. $292-294$.

2.Карпова IО. Г. Имитационное моделирование систем. Введение в моделирование с AnyLogic 5. CПб.: BHV, 2006. C. $322-326$.

3.Вишневский В.М., Ляхов А.И., Портной С.Л., Шахнович И. В. Широкополосные беспроводные сети передачи информации. Техносфера. 2005. С. 282-286.

4.Мочалов В.А. Метод синтеза отказоустойчиваой структуры сенсорной сети при наличии ограничений по размещению узлов сети в разнородном пространстве. Т-сот. Техно.тогии информационного общества. №10. 2012. С. 71-75.

5.Антонова Г.М., Титов А.П. Моделирование информационных потоков в электронном государстве. -Управ.ление развитием крупномасштабных систем (MLSD'2011): Материалы Пятой международной конференции. Том 2. М.: ИПУ РАН, 2011. C. $325-328$.

6.Умнов А.Л., Головачев Д.А., Ковалев П.А., ІПишалов И.С. Система сбора информации с узлов сенсорной сети // Радиотехника. Нелинейный мир. 2005. Т.2 № 4. С. 152-167.

7. Выборнова А.И. Исследование ТСР/ІР протоколов в беспроводных сенсорных сетях. Санкт-Петербургский университет телекоммуникаций им. проф. М.А Бонч-Бруевича, 2014. $180 \mathrm{c.}$

8. Culler D., Lee N., Levis P.. TOSSIM: accurate and scalable simulation of entire TinyOS application // In Proc. Of 1 Int. Conf. on Embedded Networked Sensor Systems, Los Angeles; CA, USA, 2009. P. 263-266.

9. Heidemann W.Ye, J., Estrin D.. An Energy-Efficient MAC protocol for Wireless Sensor Networks // In Proc. Oo IEEE Infocom Int. Conf., June USA, New York, NY, 2013. P. 532-537.

10.Bahrein R., Welsh M., Gay D., Culler D.. The nesC Language: A Holistic Approach to Networked Embedded Systems. // InACM SIGPLAN Not., 2013. Vol. 18(2): P. 12-14.

11. Shah S. B. H et al., "OPEN: Optimized Path Planning Algorithm with Energy Efficiency and Extending Network Lifetime in WSN", Journal of Computing and Information Technology, vol. 25, no. 1, pp. 1-14, 2017. http://dx.doi.org/10.20532/cit.2017.1003259.

12. Golubnichaya E. Analysis of wireless sensor networks characteristics // 4th International Scientific-Practical Conference Problems of Infocommunications. Science and Technology (PIC S\&T), 2017, P. 261-263.

13. Essafi S. , Tahar E., "Performance Improvement of the Wireless Body Area Network (WBAN) under Interferences", in IEEE 18th International Conference on e-Health Networking, Applications and Services (Healthcom), Munich, Germany, 2016, pp 1-6. https://doi.org/10.1109/HealthCom.2016.7749507.

\section{REFERENCES}

1. Antonova G.M., Titov A.P. E-Governance instrument ehlektronnogo gosudarstv. -Upravlenie razvitiem krupnomasshtabnykh sistem (MLSD'2011): Materialy Pyatoy mezhdunarodnoy konferentsii. Tom 2. M.: IPU RAN, 2011. S. 292-294.

2. Karpova Yu. G. Imitatsionnoe modelirovanie sistem. Vvedenie v modelirovanie s AnyLogic 5. SPb.: BHV, 2006. S. $322-326$.

3. Vishnevskiy V.M., Lyakhov A.I., Portnoy S.L., Shakhnovich I. V. Shirokopolosnye besprovodnye seti peredachi informatsii. Tekhnosfera. 2005. S. 282-286.

4. Mochalov V.A. Metod sinteza otkazoustoychivaoy struktury sensornoy seti pri nalichii ogranicheniy po razmeshcheniyu uzlov seti v raznorodnom prostranstve. T-com. Tekhnologii informatsionnogo obshchestva. №10. 2012. S. 71-75.

5. Antonova G.M., Titov A.P. Modelirovanie informatsionnykh potokov v ehlektronnom gosudarstve. -Upravlenie razvitiem krupnomasshtabnykh sistem (MLSD'2011): Materialy Pyatoy mezhdunarodnoy konferentsii. Tom 2. M.: IPU RAN, 2011. S. $325-$ 328.

6. Umnov A.L., Golovachev D.A., Kovalev P.A., Shishalov I.S.. Sistema sbora informatsii s uzlov sensornoy seti // Radiotekhnika. Nelineynyy mir. 2005. T.2 № 4. S. 152-167.

7. Vybornova A.I. Issledovanie TCP/IP protokolov v besprovodnykh sensornykh setyakh. Sankt-Peterburgskiy universitet telekommunikatsiy im. prof. M.A Bonch-Bruevicha, 2014. $180 \mathrm{~s}$.

8. Culler D., Lee N., Levis P.. TOSSIM: accurate and scalable simulation of entire TinyOS application // In Proc. Of 1 Int. Conf. on Embedded Networked Sensor Systems, Los Angeles; CA, USA, 2009. P. 263-266.

9. Heidemann W.Ye, J., Estrin D.. An Energy-Efficient MAC protocol for Wireless Sensor Networks // In Proc. Oo IEEE Infocom Int. Conf., June USA, New York, NY, 2013. P. 532-537.

10. Bahrein R., Welsh M., Gay D., Culler D.. The nesC Language: A Holistic Approach to Networked Embedded Systems. // InACM SIGPLAN Not., 2013. Vol. 18(2): P. 12-14.

11. Shah S. B. H et al., "OPEN: Optimized Path Planning Algorithm with Energy Efficiency and Extending Network Lifetime in WSN", Journal of Computing and Information Technology, vol. 25, no. 1, P. 1-14, 2017. http://dx.doi.org/10.20532/cit.2017.1003259. 
12. Golubnichaya E. Analysis of wireless sensor networks characteristics // 4th International Scientific-Practical Conference Problems of Infocommunications. Science and Technology (PIC S\&T), 2017, P. 261-263.

13. Essafi S., Tahar E., "Performance Improvement of the Wireless Body Area Network (WBAN) under Interferences", in IEEE 18th International Conference on e-Health Networking, Applications and Services (Healthcom), Munich, Germany, 2016, pp 1-6. https://doi.org/10.1109/HealthCom.2016.7749507

\section{OБ ABTOPAX | ABOUT AUTHORS}

Капустиш Сергей В.адимирович, аспирант, кафедра КБ-5 «Аппаратное, программное и математическое

обеспечение вычислительных систем» МИРЭА - Российский технологический университет.

Kapustin Sergey Vladimirovich, Postgraduate, Department of Hardware, software and mathematical support of computer systems, MIREA-Russian technological University

HOC

Халабия Рустам Фарук, кандидат технических наук, Доцент, кафедра КБ-5 «Аппаратное, программ-

и математическое обеспечение вычислительных систем», МИРЭА - Российский технологический университет

Khalabia Rustam Farooq, Candidate of Technical Sciences, Associate Professor, Department of Hardware, software and mathematical support of computer systems, MIREA-Russian technological University

Дата поступления в редакцию:25.01.2020

После рецензирования:23.02.2020

Дата принятия к публикации:03.03.2020 